\title{
De Nederlandse Opstand in de geschiedbeoefening door buitenlanders 1885-1985
}

\author{
A.F. MELLINK
}

Ongeveer aan het begin van het honderdjarig tijdvak dat hier in beschouwing wordt genomen, in 1887, schreef Moriz Ritter een artikel in de Historische Zeitschrift over de beginperiode van de Nederlandse Opstand ${ }^{1}$. Hij wees daarin op de enorm aangezwollen hoeveelheid uitgegeven bronnen over het onderwerp, dankzij de arbeid van Groen van Prinsterer in Nederland en Gachard in België en van anderen die hun voorbeeld volgden. Hij betreurt echter dat er nog geen geschiedschrijver is opgestaan die met behulp van de vele verrichte voorstudiën een volledig beeld van het gehele gebeuren heeft ontworpen. De auteur van de 'meisterhafte Skizze' van 1859: 'Het Voorspel van den tachtigjarigen oorlog' en van de reeds eerder gepubliceerde Tien jaren uit den tachtigjarigen oorlog, Robert Fruin, wordt dan met name aangewezen als in gebreke gebleven. Ritter roept de clementie van zijn Nederlandse vakgenoten in voor zijn eigen specialistische bijdrage tot de geschiedenis der jaren 1559-1566 die hij aanbiedt. Het is een voorbeeld van de levendige belangstelling die in de kring van de beoefenaren der Duitse geschiedwetenschap voor het thema de Nederlandse Opstand bestond, een belangstelling die in de loop der decennia nog menige competente bijdrage zou opleveren. Althans in de eerste helft van het hier besproken tijdvak zou het Duitse aandeel in feite domineren in de bestudering van de Opstand door buitenlanders.

Ritter verwijst mede naar de situatie der Nederlandse geschiedbeoefening op dit punt in het laatste kwart der vorige eeuw. Naar de mening van G.W. Kernkamp was na 1870 het grote tijdperk der Nederlandse historiografie afgesloten en sindsdien had men zich tot detailarbeid gezet ${ }^{2}$. Fruin had reeds in de aanhef van zijn 'Voorspel' duidelijk gemaakt zijn taak voornamelijk te zien in aanvulling en verbetering van een reeds bestaande algemene beschrijving, Motiey's Rise of the Dutch Republic van 1856, dat inmiddels ook in Nederlandse vertaling was

1. M. Ritter, 'Über die Anfange des niederlandischen Aufstandes', Historische Zeitschrift, LVIII (1887) $385 \mathrm{vlg}$.

2. G.W. Kernkamp, Van menschen en tijden (Haarlem, 1931) 21. 
verschenen ${ }^{3}$. Rijksarchivaris Bakhuizen van den Brink achtte de arbeid van Motley van zoveel gewicht dat hij de vertaling van een inleiding en soms diepgravende aantekeningen voorzag. Het werk van de Amerikaan Motley, dat door Moriz Ritter in bovengenoemd artikel niet vermeld wordt, markeerde dus een belangrijke etappe in de geschiedschrijving van de Nederlandse Opstand en het was ook een bijzonder duidelijk voorbeeld van de wijze waarop de buitenlandse bijdrage door de Nederlandse vakbeoefenaren werd verwerkt. Toen zomin als later was er sprake van een isolement van de vaderlandse geschiedstudie op dit punt ten opzichte van de invloeden van buiten. Motley staat als tot dramatiseren geneigd verheerlijker van het streven naar staatkundige en godsdienstige vrijheid der $\mathrm{Ne}$ derlanden in de zestiende eeuw in een traditie die uiteraard diepe wortels had. Opmerkelijk is dat de auteur die zelfs van de deugden van het 'Anglo-Saxon race' gewaagt ${ }^{4}$, daarbij op een Germaanse oorsprong doelt en de neiging heeft om een Germaans-Romaanse tegenstelling te accentueren. Bakhuizen van den Brink heeft hierop reeds de vinger gelegd: de band met het Duitse rijk was reeds voor de Opstand doorgesneden ${ }^{5}$.

Jan Romein in zijn 'Spieghel Historiael' bevestigt dat er na Motley nauwelijks een poging is gewaagd tot het schrijven van een samenvattend werk over de Opstand, afgezien van de rooms-katholieke auteur Nuyens, die op zijn wijze op Motley reageerde, en dat men zich tot 'stukwerk' heeft beperkt ${ }^{6}$. Dit oordeel strekt hij ook uit tot de buitenlanders die zich met de stof hebben bezig gehouden ${ }^{7}$. Opmerkelijk is dan ook dat twee Angelsaksische auteurs die in het laatste decennium der vorige eeuw zich aan een biografie van Willem van Oranje waagden, beiden min of meer in het voetspoor van Motley lopen, die de Prins als held van de Opstand had geïdealiseerd. Dit geldt zowel voor de Engelse wijsgerige schrijver Frederic Harrison, die in 1897 een essay aan William the Silent wijdde, als voor de Amerikaanse Ruth Putnam, wier in 1895 verschenen biografie in 1911 nog in een geheel nieuwe bewerking uitkwam. Vooral deze laatste mag tot het genre goed geschreven historiewerken gerekend worden dat voor een breed publiek aantrekkelijk is, maar ondanks degelijk bronnengebruik weinig aan de kennis van het onderwerp toevoegt. De Nederlandse Oranje-biograaf P.J. Blok sprak in dit geval zelfs van een 'scheef geteekend beeld' bij alle door hem ook wel erkende verdiensten ${ }^{8}$.

Wat betreft buitenlandse invloed op de geschiedbeoefening terzake van de Ne-

4. J.L. Motley, The Rise of the Dutch Republic (Londen, 1899) vi.

5. R.C. Bakhuizen van den Brink, Inleiding bij J.L. Motley, De opkomst van deNederlandsche Republiek, I ('s-Gravenhage, 1859) ix vlg.

6. J. Romein, In opdracht van de tijd (Amsterdam, 1946) 136.

7. Ibidem, 140.

8. P.J. Blok, Willem de Eerste, II (Amsterdam, 1920) 241. 
derlandse Opstand moet echter voor de gehele periode tot aan de tweede wereldoorlog zonder twijfel de ereplaats worden toegekend aan de Duitse historicus Felix Rachfahl. Na een eerste monografische arbeid over de landvoogdes Margaretha van Parma te hebben volbracht (1898) wijdde hij zich aan de figuur van Oranje als spil van de Opstand. Een lijvig driedelig werk is hieruit voortgekomen, dat met inbegrip van de aantekeningen de omvang van tweeduizend bladzijden overschrijdt en toch nog slechts een torso is, dat niet verder gaat dan het jaar 1569, toen de eigenlijke carrière van de Prins als opstandsleider nog beginnen moest. Deel I verscheen in 1906, deel II, dat uit twee 'Halbbande' bestaat, in 1907-1908, daarna kwam er een onderbreking ten gevolge van de eerste wereldoorlog en pas in 1924 kon deel III uitkomen dankzij de actieve belangstelling van Nederlandse kant (met name van de latere Oranje-biograaf Van Schelven) bij uitgeverij Martinus Nijhoff te 's-Gravenhage. Het aangekondigde vierde deel, dat de studie had moeten afsluiten, is door het overlijden van de schrijver kort nadien niet meer verschenen.

Rachfahl had de ambitie om de stof die hij met name in Belgische en Duitse archieven aantrof, tot een 'abschlieszende Darstellung' te verwerken, waarbij door hem naar de hoogste graad van volledigheid werd gestreefd ${ }^{9}$. Een tweede Motley is hij met dat al niet geworden: reeds Blok noemde zijn werk meer 'een rijk voorzien magazijn van informatie' dan een boek ${ }^{10}$ en Romein achtte het een duidelijk voorbeeld ervan hoe met de verwetenschappelijking van de geschiedschrijving de behoefte aan een scherp beeld tegelijk met dat beeld zelf is gaan vervagen ${ }^{11}$. Dit laatste gold zeker ook voor Ernst Marx, die in 1902 zijn Studiën zur Geschichte des niederlandischen Aufstandes publiceerde na kennisneming van de inhoud van Joachim Hopperus 'Recueil et mémorial des troubles des Pays-Bas du Roy' over de periode 1559-1564. Rachfahl heeft zijnerzijds met Marx breedvoerig gepolemiseerd over het onderwerp, zowel in 1903 als in 1910, in de Westdeutsche Zeitschrift für Geschichte und Kunst. Zijn hoofdwerk blijft ondanks het specialistische karakter ervan door zijn brede opzet en gedegen documentatie een unieke prestatie, die ook na zoveel decennia nog zijn waarde heeft behouden. Zijn schets van de sociale, politieke en godsdienstige toestand der Nederlanden (in deel I), zijn aandacht voor de positite van de adel in zijn verschillende geledingen verdienen daarbij gememoreerd te worden. Een behandeling van de periode van het Voorspel als in deel II heeft met een dergelijke uitvoerigheid sindsdien niet meer plaatsgevonden. De rol van de hoge adel in dat tijdsbestek, krijgt hier alle reliëf en geconstateerd wordt hoe bij alle tendensen tot feodalisering van het centrale

9. F. Rachfahl, Wilhelm von Oranien und der niederlandische Aufstand, II (Halle, 1907-1908) Vorrede.

10. Blok, Willem de Eerste, II, 242.

11. Romein, In opdracht, 89. 
en gewestelijke bestuur van deze zijde de groten toch in brede burgerlijke kring als 'natürlichen Verbündeten gegen die absolutistischen Bestrebungen der Krone und gegen ihre Religionspolitik' worden beschouwd ${ }^{12}$.

Het is bekend dat de Belgische historicus Henri Pirenne in zijn Histoire de Belgique geheel andere accenten legde bij de waardering van het nationale 'Bourgondische' verzet tegen de 'état espagnol', een verschil van zienswijze dat bijvoorbeeld aan Van Schelven later weer gelegenheid bood tot eigen bespiegelingen op dit punt ${ }^{13}$. Terloops moge hier nog opgemerkt worden dat de uiteenzettingen van Rachfahl over het optreden van de hoge adel in de eerste fase van het verzet en van de landadel daarna in de dagen van het Compromis en later weinig steun bieden aan recentere geschiedschrijvers die wat al te krampachtig anti-feodale strekkingen in de ontwikkeling van de Nederlandse revolutie der zestiende eeuw wilden onderkennen. Rachfahls derde en laatste deel bestrijkt de jaren 1567-1569, waarvoor hij zich vooral op materiaal uit Duitse archieven heeft gebaseerd, in zo sterke mate dat zeker in dit deel de Duitse optiek geheel is gaan overheersen. Het gaat immers om een periode waarin de Prins steun tracht te verkrijgen in de kring van de Duitse vorsten voor zijn plannen tot bevrijding van de Nederlanden. De internationale aspecten van de beginnende Nederlandse Opstand, met name de nauwe samenhang daarvan met de ontwikkelingen in Frankrijk, geraken aldus op de achtergrond. De Nederlandse historicus Enno van Gelder, die ook voor de betekenis van de adel in de Opstand zulk een juist gevoel bleek te hebben, heeft in 1930 reeds in een bekende lezing de parallel tussen het optreden der Hugenoten in Frankrijk en het gelijktijdig gebeuren in de Nederlanden getrokken ${ }^{14}$.

Belangrijke facetten der geschiedenis van de eigenlijke Nederlandse Opstand, met name in de jaren zeventig, waaraan Rachfahl in het geheel niet is toegekomen, vinden we behandeld in een te Berlijn verschenen Belgisch werk dat nog wel tot de periode van het interbellum mag worden gerekend, dat van Leo Delfos, DieAnfange der Utrechter Union 1577-1587 (1941). Het draagt als ondertitel terecht de aanduiding 'ein Beitrag zur Geschichte der niederlandischen Erhebung, insbesondere zu deren Verfassungsgeschichte'. Een ouder basiswerk op dit terrein van de hand van Fruins tijdgenoot P.L. Muller dateerde al van 1867, al hadden ook lateren zich wel met deze problemen bezig gehouden. Juist omdat hij meer afstand kon nemen van de Noordnederlandse zienswijzen die sinds Muller ingang gevonden hadden, is het werk van Delfos van grote waarde. Het centrale probleem is de verhouding van de nadere Unie van Utrecht tot de generale Unie, die in de Staten-Generaal haar belichaming vond. De door de Prins en zijn broer

12. Rachfahl, Wilhelm von Oranten, II, 402-403.

13. A.A. van Schelven, Willem van Oranje (Amsterdam, 1943) 54 vlg.

14. Cf. de recensie door H.A. Enno van Gelder van Rachfahls derde deel (Tijdschrift voor Geschiedenis (TvG), XL (1925) 199). 
Jan in dezen gevolgde lijn komt daarbij aan de orde. De auteur rekent op grond van zijn diepgaand onderzoek ten enenmale af met de voorstelling als zou met de Unie van Utrecht in 1579 een scheiding tussen Noord en Zuid zijn beoogd (nog veertig jaar later, in 1981, werd echter in een Duitse publikatie gesproken over de 'endgültige Teilung der Niederlande' die met de Unies van Atrecht en Utrecht zijn beslag zou hebben gekregen ${ }^{15}$ ). In feite werden door de Waalse gewesten Artois en Henegouwen, waar adel en clerus invloedrijk waren, afscheidingspogingen gerealiseerd, maar Vlaanderen en Brabant bleven nog jarenlang meewerken in het kader der nadere Unie die gaandeweg trouwens in de praktijk met de organen der generaliteit ineensmolt.

Met het boek van Delfos dat ondanks de tijdsomstandigheden hier te lande toch wel aandacht vond ${ }^{16}$, is een zekere periode afgesloten waarin vooral de Duitse bijdrage tot de historiografie van de Opstand toonaangevend is geweest. De overgang tot het volgende tijdvak wordt eigenlijk al gevormd door een in 1944 verschenen biografische studie van Engelse kant, de Willem de Zwijger-biografie van CV. Wedgwood. Het werk behoort tot de categorie waartoe eerder de arbeid van R. Putnam gerekend moet worden, goed geschreven en goed gedocumenteerd ook, maar met meer aandacht voor de persoonlijke factoren dan voor de drijfkrachten der grote politiek van die dagen. Een zeer bevoegd beoordelaar merkt bovendien op dat het 'wemelt van onjuistheden' ${ }^{17}$.

De ware opening van een nieuwe era wordt gevonden in de beknopte maar magistrale verhandeling van G.N. Clark, The Birth of the Dutch Republic. Dit is niet alleen toe te schrijven aan het tijdstip van verschijning (1946), hoezeer de recente ervaringen van de tweede wereldoorlog er ook in doorklinken. Een diepgaande belangstelling van Engelse zijde voor de geschiedenis der Nederlanden in de zestiende eeuw, mede bevorderd door Geyls activiteit op zijn leerstoel te Londen sinds 1924, kwam hier tot uitdrukking. Vrijwel alle facetten van de Nederlandse Opstand komen in dit toch summiere relaas aan de orde en worden met een bewonderenswaardige kennis van zaken voorgedragen. Er is om te beginnen het juiste gevoel voor de internationale samenhang der gebeurtenissen, met name van die in de Nederlanden en die in Frankrijk, en ook voor de grote draagwijdte van het verzet tegen de vorstelijke tirannie, dat alleen in de Lage landen in deze eeuw tot een overwinning leidde, zoals later in Engeland. Er is de opmerkelijke,

15. R. Saage, Herrschaft, Toleranz, Widerstand. Studiën zurpolitischen Theorie der Niederlandischen und der Englischen Revolution (Frankfurt am Main, 1981) 91.

16. N. Japikse in: Bijdragen voor vaderlandsche geschiedenis en oudheidkunde, VIII, iii (1942) 273 vlg. en H.A. Enno van Gelder in: TvG, LIX (1946) 112 vlg. De Belg Delfos woonde en werkte in Duitsland.

17. K.W. Swart in: CA. Tamse, ed., Nassau en Oranje in de Nederlandse geschiedenis (Alphen aan den Rijn, 1979) 407. 
kritische en deskundige beschouwing over Geyls accentuering van het taalprobleem, dat aan Clark in de zestiende-eeuwse situatie ten slotte minder belangrijk voorkomt als staatsvormende factor dan de (calvinistische) religie van die dagen. Niet toevallig verwijst de schrijver voortdurend naar de publikaties van wie in de decennia voor en na de tweede wereldoorlog wel de beste Nederlandse kenner van de Opstand is geweest: Enno van Gelder. De politiek van Oranje in de jaren zeventig wordt getekend als het streven naar een algemeen verzet der zeventien $\mathrm{Ne}$ derlanden rondom de protestantse kern (Holland en Zeeland), óók van de katholiekgezinde gewesten. Uiteindelijk moest hij terugvallen op het Noordelijk bolwerk dat zich door zijn macht ter zee wist te handhaven (ook Geyls grote rivierenthese wordt aldus gekritiseerd). Een maritieme staat met een losse federale structuur en een grote mate van religieuze tolerantie was het eindresultaat.

In één passage doelt Clark op de marxistische geschiedschrijving, wanneer hij gewaagt van 'the crude theories which explain away national feeling, political liberty and religious beliefs as by-products of economie life ${ }^{\prime 18}$. Dit oordeel kan nog niet slaan op het in 1949 verschenen werk van de Duitse antifascistische emigrant Erich Kuttner over Het hongerjaar 1566, waarin de beeldenstorm van dat jaar aan de hand van een uitgebreide bronnenstudie wordt geanalyseerd. Dit boek van een niet-historicus, die onder de moeilijkste omstandigheden arbeidde, is over het geheel toch wel als opmerkelijke prestatie beoordeeld bij alle kritiek op het schematisme van de schrijver, waarmee hij zeker onder de categorie valt welke Clark op het oog had. Maar de sociale dimensie van de Opstand is door hem, hoe dan ook, duidelijker dan ooit aan de orde gesteld, hoezeer uit het werk een geringschatting spreekt voor de zelfstandige betekenis van godsdienstige en politieke factoren ${ }^{19}$.

Het door J.W. Smit in 1959 uitgesproken oordeel dat 'in the years after the Second World War very little of importance has been published' (aangaande de Opstand der Nederlanden) ${ }^{20}$ kan niet geheel gemotiveerd geacht worden in het licht van de publikaties die in de jaren vijftig verschenen zijn. Allereerst moge hier een studie van de Amerikaan Gordon Griffiths genoemd worden, een biografie uit 1954 van een tweede plan-figuur uit de Opstand, de adellijke Willem van Hoorne, heer van Heze, die een rol speelde bij de staatsgreep van 4 september 1576 te Brussel, voorafgaand aan de gebeurtenissen die tot de Pacificatie van Gent leidden. Dezelfde auteur, die zich als gezaghebbend werker op het terrein van de geschiedenis der vertegenwoordigende instellingen zou doen kennen, hield zich ook verder met bronnenstudie aangaande de Opstand bezig. Op grond daar-

18. G.N. Clark, The Birth of the Dutch Republic (Oxford, 1975) 127.

19. Cf. J.W. Smit, 'The Present Position of Studies Regarding the Revolt of the Netherlands', in:

J.S. Bromley en E.H. Kossmann, ed., Britain and the Netherlands (Londen, 1960) 25 vlg.

20. Ibidem, 11 . 
van publiceerde hij een bijdrage 'The Revolutionary Character of the Revolt of the Netherlands', waarin hij trachtte na te gaan of de fasen van de Nederlandse Opstand ook overeenkwamen met die van de Engelse, Amerikaanse, Franse en Russische revoluties, zoals met name Crane Brinton deze in zijn Anatomy ofRevolution had onderscheiden ${ }^{21}$. Voorts moge de werkzaamheid van H.G. Koenigsberger genoemd worden, die zich sinds de tweede wereldoorlog op het brede gebied van de geschiedenis der parlementaire lichamen en de revolutionaire bewegingen der zestiende eeuw bewoog en daarvan in menige bijdrage ook betreffende de Nederlanden getuigenis aflegde ${ }^{22}$. De meest principiële verhandeling van zijn hand ten aanzien van de Nederlandse Opstand is wel zijn artikel 'The Organization of Revolutionary Parties in France and the Netherlands during the Sixteenth Century' van $1955^{23}$. Het is niet alleen van belang op het stuk van de politiekgodsdienstige partijvorming van het tijdvak, maar mede voor de sociale context daarvan, die door Kuttner zozeer op de voorgrond was geplaatst. Koenigsberger gaat er van uit dat in het geval van de hugenoten en de geuzen goed georganiseerde oppositiebewegingen van een minderheid tot stand kwamen, steunend op de aaneensluiting van heterogene sociale elementen (adel, burgerij, handwerkslieden) en bijeengehouden door het bindmiddel van de calvinistische religie. Ook de Heilige Liga der Franse rooms-katholieken laat hij echter onder dit schema vallen. Zelfs meent hij hiermee de oorsprong ontdekt te hebben van de latere organisatie der jacobijnen en der twintigste-eeuwse totalitaire partijen. Bezondigt deze auteur zich hier toch aan het door Moriz Ritter gelaakte euvel 'Gegensatze und Ziele der Gegenwart in die Vergangenheit zu verlegen ${ }^{24}$ ? Dit risico is niet geheel afwezig, maar zijn kennis van het verloop ook der Nederlandse gebeurtenissen is grondig. Vooral zijn onderstreping van het samengaan van lagere adel, burgerij en volksklassen in de Opstand verdient de aandacht. In het bijzonder belicht hij de toespitsing van de sociaal-politieke tegenstellingen in de Zuidnederlandse gewesten na 1576, als de hoge Waalse katholieke adel enerzijds, de radicale stedelijke democratie met name te Gent anderzijds tegenover elkaar komen te staan.

Dit laatste probleem krijgt ook veel aandacht in een anno 1958 verschenen Sowjetrussische studie over de Nederlandse burgerlijke omwenteling der zestiende eeuw van de hand van een specialist op dit terrein, A.N. Tsjistozwonof. Het boek is niet de eerste marxistische studie over de Opstand, ook niet van Sowjetrussi-

21. G. Griffiths, 'The Revolutionary Character of the Revolt of the Netherlands', Comparative Studies in Society and History, II (1959-1960) 452 vlg.

22. H.G. Koenigsberger, Estates and Revolutions. Essays in Early Modern European History (Ithaca-Londen, 1971).

23. Ibidem, $224 \mathrm{vlg}$.

24. Ritter, 'Über die Anfange', 386. 
sche zijde, maar als publikatie van de Academie van Wetenschappen der USSR draagt het een enigermate officieel karakter. In Nederland is het werk nader bekend gemaakt door een bespreking van de hand van Z.R. Dittrich, die zeer kritisch gestemd is ${ }^{25}$. Hoewel de auteur betrekkelijk weinig Nederlandse literatuur blijkt te kennen, is hij toch van de materie in het algemeen wel op de hoogte, geheel afgezien van zijn interpretaties. Een kardinaal punt is wel de hantering door Tsjistozwonof van de begrippen feodalisme of feodale orde tegenover de opkomende burgerlijke klasse. Hier rijzen onvermijdelijk problemen, gezien de grote rol van Oranje èn de adel in het algemeen vanaf het begin der opstandige bewegingen. De positie van de Prins als politiek leider wordt getypeerd als halfslachtig en opportunistisch, zo niet reactionair. $\mathrm{Na}$ de Pacificatie bleven de StatenGeneraal in gebreke de vooral in het Zuiden in de steden en ten plattelande dominerende feodale verhoudingen te liquideren ${ }^{26}$. Voor Oranjes bedachtzaam beleid en voor zijn tolerantiepolitiek bestaat weinig waardering. Toch had een andere Sowjetrussische historicus nog in het pre-stalinistische tijdperk over hetzelfde onderwerp in geheel andere geest geschreven, zoals Romein in zijn oratie 'Het vergruisde beeld' meedeelt. Het was N.M. Pakoelj, die in een boek van 1931 het resultaat der Nederlandse burgerlijke revolutie beschreef als bevochten 'met behulp, maar tegelijk ten detrimente van de feodale adel', hetgeen een heel wat genuanceerder voorstelling van zaken is ${ }^{27}$.

Uit hetzelfde jaar 1958 waarin het boek van Tsjistozwonof verscheen, stamt ook een nieuwe bijdrage van Duitse zijde, de dissertatie van Horst Lademacher, Die Stellung des Prinzen von Oranien als Statthalter in den Niederlanden von 1572 bis 1584. Eigenlijk is dit werk ('ein Beitrag zur Verfassungsgeschichte der Niederlande') een soortgelijke studie als die van Delfos uit 1941. Het vormt een belangrijke bouwsteen voor de kennis van het tijdvak, in het bijzonder naar de staatsrechtelijke kant. Het gaat hier dus minder om de persoon van Oranje of zijn godsdienstige en staatkundige denkbeelden dan wel om de ontwikkeling van het stadhouderlijk ambt tegenover de Staten (in Holland met name) in de jaren van de Opstand vanaf 1572 tot de dood van de Prins. Gesuggereerd wordt dat hier het begin ligt van de groei naar een constitutioneel-monarchale positie ${ }^{28}$.

Een duidelijk produkt van de periode van destalinisatie in de Oosteuropese geschiedschrijving is het overigens pas in 1969 uitgekomen boek van de Hongaar Tibor Wittman, Les gueux dans les bonnes villes de Flandre (1577-1584). Het was al in 1961 gereed, maar verscheen pas jaren later in Franse vertaling bij de Hon-

25. Bijdragen voor de geschiedenis der Nederlanden, XIV (1960) $57 \mathrm{vlg}$.

26. Ibidem, 64.

27. Romein, In opdracht, 89.

28. H. Lademacher, Die Stellung des Prinzen von Oranien als Statthalter in den Niederlanden von 1572 bis 1584 (Bonn, 1958) 179. 


\section{A.F. MELLINK}

gaarse Academie van Wetenschappen. De schrijver heeft in 1957 enige tijd in België doorgebracht en hij heeft zich ook later voornamelijk gedocumenteerd met behulp van Zuidnederlandse publikaties, wat de aard van zijn speciale onderwerp natuurlijk meebracht. Wittman is een historicus die naar een niet-dogmatische toepassing van het marxisme streeft. De eerste bladzijde van zijn boek bevat dan ook geen obligate verwijzing naar Lenin, maar een naar het werk van Braudel over het Middellandse Zeegebied in de tijd van Filips II $^{29}$. Over het geheel heeft de Franse geschiedschrijving weinig speciale studies met betrekking tot de Nederlandse Opstand opgeleverd, maar Braudels hoofdwerk markeert toch een etappe, waar het de gebeurtenissen van 1566 en volgende jaren in de Nederlanden plaatst in het kader van de ontwikkeling der dingen in Zuid-Europa. Hoewel ook Braudel nagenoeg geen Noordnederlandse literatuur benut, is zijn karakteristiek van de situatie der Nederlanden in de zestiende eeuw toch trefzeker:

Un pays libre, avec ses franchises, ses sécurités politiques et ses privileges d'argent; une seconde Italië, tres urbanisée, 'industrialisée', dépendante du dehors, difficile a gouverner pour cette raison et quelques autres. Restée terrienne d'ailleurs, plus qu'on ne Ie pense, et, de ce fait, dotée d'une puissante aristocratie ${ }^{30}$.

Hier zijn uit de losse hand enkele trekken van de vroeg-burgerlijke en ook nog feodale situatie der Nederlanden weergegeven - een complex probleem, waarmee Wittman zozeer worstelt. Hij gaat weliswaar tot op zekere hoogte pragmatisch te werk en oefent ook wel kritiek op het boek van Tsjistozwonof. Evenals ten aanzien van de Duitse Boerenoorlog van 1525 in de DDR bijvoorbeeld was er een periode van ruimere discussievrijheid aangebroken, al bleef dit alles zich afspelen in het raam van bepaalde thesen over de vroeg-burgerlijke revolutie, zoals ook bij Wittman eigenlijk het geval is. Voortdurend bezigt hij het begrip feodalisme in zeer algemene zin en toetst hij de tendenties in de Nederlandse opstandige gewesten aan hun antifeodaal gehalte. Toch moet hij duidelijk tot uitdrukking brengen dat de agrarische situatie hier anders was dan in het zeventiende-eeuwse Engeland, waar de gentry zulk een rol speelde. De eerste burgerlijke revolutie in Europa heeft het dus zonder uitgesproken steun van boerenzijde moeten stellen, hoe weinig dit dan ook strookt met de gebruikelijke leninistische visies ${ }^{31}$.

In 1970, vijfentwintig jaar bijna na de verhandeling van Clark, verscheen er weer een indringende studie over de Nederlandse Opstand van Engelse zijde, het boek van Charles Wilson Queen Elizabeth and the Revolt of the Netherlands.

29. T. Wittman, Les gueux dans les bonnes villes de Flandre 1577-1584 (Budapest, 1969) 7.

30.. F. Braudel, La méditerranée et le monde méditerranéen a l'époque de Philippe II, II (Parijs, 1966) 340.

31. Wittman, Les gueux, $405 \mathrm{vlg}$. 
Weliswaar ging het hier vooral om een onderzoek naar de buitenlandse politiek van Elizabeth ten aanzien van de Nederlanden gedurende dit tijdvak. De hevige polemiek die de auteur daaromtrent met vakgenoten als R.B. Wernham voert, mag niet doen voorbijzien aan de waardevolle bijdrage tot de geschiedschrijving over de Opstand die dit werk mede vormt. Ook Wilson breekt de staf over Geyls grote rivieren-these in het eerste hoofdstuk van zijn boek, niet zonder een vleugje ironie $^{32}$. Zijn verdienste is vooral dat hij de aandacht vestigt op de dominerende positie van de adel met name in de zuidelijke gewesten als belangrijke sociaalpolitieke factor voor het verloop van de Opstand. In zijn derde hoofdstuk gaat hij hierop aan de hand van onder andere Rachfahl diep in en schetst hij de van oorsprong meest Waalse hoge adel als in feite anti-Spaansgezind en behorend tot de groepering der 'politieken'. Iemand uit hun kring, de jongere broer van Granvelle Frederik Perrenot, baron van Champagney, werd in 1576 naar Elizabeth afgevaardigd door landvoogd Requesens nog, tegelijk ongeveer met een missie van het gewest Holland onder leiding van Marnix van Sint Aldegonde. Het verschil in behandeling die hun ten deel viel was opvallend, want Elizabeth kon niet wennen aan de idee dat 'tradesmen could create a nation-state or that they were fit and proper persons for a monarch to deal with ${ }^{133}$. Juist in de beslissende fase van de algemene Opstand na 1576 bleef zij aarzelen ten aanzien van hulpverlening aan de Nederlandse gewesten, die in Oranje een 'leader of genius' hadden gevonden ${ }^{34}$. De fatale gevolgen daarvan bleven niet uit, toen Parma de zwevende adelsklasse voor zijn zaak wist te winnen en het Zuiden voor de Opstand verloren ging. Nederlandse recensenten als J.C. Boogman en J.J. Woltjer hebben aan het boek van Wilson uitvoerig aandacht besteed ${ }^{35}$. Zij hebben de daarin op het beleid van Elizabeth uitgeoefende kritiek over het geheel als gechargeerd en niet gerechtvaardigd beoordeeld, maar afgezien hiervan blijft het werk zijn waarde behouden als competente behandeling van een cruciaal aspect van de Nederlandse Opstand.

Kort hierna valt de eerste publikatie in boekvorm van Geoffrey Parker te signaleren: The Army ofFlanders and the Spanish Road, welk onderwerp nader omschreven wordt als 'The Logistics of Spanish Victory and Defeat in the Low Countries' Wars' (1972). De ondertitel duidt al aan dat de auteur zich heeft geconcentreerd op wat hij zelf noemt 'the mechanics of the conflict ${ }^{36}$, en dat wel met name aan de Spaanse zijde. Aan de totstandkoming van deze studie is een zeer intensief onderzoek van archivalia in tal van Europese landen voorafgegaan,

32. Charles Wilson, Queen Elizabeth and the Revolt of the Netherlands (Londen, 1970) 8 vlg.

33. Ibidem, 15.

34. Ibidem, 50.

35. Respectievelijk BMGN, LXXXVI1 (1972) 94 vlg. en $T v G$, LXXXV (1972) 31 vlg.

36. G. Parker, The Army ofFlanders and the Spanish Road (Londen, 1972) ix. 
in het bijzonder te Brussel en Simancas. Vraagstukken als samenstelling en recrutering van de grote heterogene Spaanse legermacht in de Nederlanden, bevoorrading, financiering en bevelvoering worden onder de loep genomen, zodat een zeer gevarieerd beeld ontstaat van de lotgevallen van 's konings soldaten in de loop der jaren. The Spanish Road die in de titel genoemd wordt, is de door Alva reeds gebruikte verbindingsroute van Italië naar de Nederlanden via Savoye, Franche Comté en de Elzas. Zonder twijfel mag men het boek van Parker een baanbrekende studie op het terrein van de oorlogvoering noemen, al is de auteur daarmee nog geen autoriteit ten aanzien van de Nederlandse Opstand zelf. Professor Poelhekke, die mijns inziens ten onrechte 'schaamroodbekaakt' wil betreuren dat een werk als dit niet uit Nederland zelf afkomstig is, heeft bij Parker een pro-Spaanse vooringenomenheid geproefd ${ }^{37}$. De schrijver heeft dit geloochend in het voorwoord van zijn latere The Dutch Revolt $(1977)^{38}$.

Meer dan tevoren heeft hij in dit boek ook Nederlandse literatuur gebezigd, waarvan hij eerder gesteld had dat deze de tachtigjarige oorlog 'as an essentially domestic affair' had behandeld ${ }^{39}$. We lezen nu ergens de treffende opmerking dat reeds de tijdgenoten inzagen dat 'the Netherlands were the hinge of Europe and that the outcome of the struggle would decide the direction in which the history of the continent would develop ${ }^{40}$. Bij alle betekenis van deze internationale context van de Opstand blijven er echter de 'nationaal-Nederlandse aspecten', waarvan Parker zich naar het oordeel van meer dan een beschouwer onvoldoende rekenschap heeft gegeven ${ }^{41}$. Een zeer kras voorbeeld hiervan is de opmerking dat de ketterij tegen de tijd van de afdanking van Kexel $\mathrm{V}$ in de Nederlanden een probleem was 'which was well on the way to being solved ${ }^{42}$. Men zou hier alleen willen verwijzen naar wat de rooms-katholieke expert Halkin schrijft in de aanhef van zijn hoofdstuk 'Le bilan du règne' ${ }^{43}$.

Dat ook de Duitse geschiedwetenschap steeds weer tot nieuwe creatieve bijdragen tot de studie van de Nederlandse Opstand in staat is, daarvan getuigt sinds de jaren zeventig in het bijzonder de werkzaamheid van Heinz Schilling. Reeds zijn debuut met een dissertatie over het onderwerp Niederlandische Exulanten im 16. Jahrhundert (1972) is een waardevol werkstuk op het gebied waarop onder anderen Van Schelven zich eerder had bewogen. Het óók politieke belang van de presbyteriaal-synodale organisatievorm der gereformeerden wordt hier reeds on-

37. BMGN, LXXXVIII (1973) 479 vlg.

38. G. Parker, The Dutch Revolt (Londen, 1977) 16.

39. Parker, Army offlanders, x.

40. Parker, Dutch Revolt, 277.

41. Cf. de recensie van M. Baelde, $T v G$, XCII (1979) 99.

42. Parker, Dutch Revolt, 37.

43. Léon-E. Halkin, La réforme en Belgique sous Charles-Quint (Brussel, 1957) 111. 
derstreept, een thema waaraan Schilling later in een aantal Nederlandse steden detailonderzoek zou gaan wijden ${ }^{44}$. Vanuit een zeer grondige beheersing van Noord- en Zuidnederlandse gepubliceerde bronnen en literatuur heeft deze auteur zich ook gewaagd aan een algemene positiebepaling ten aanzien van de vraagstukken rondom de Opstand in een verhandeling onder de titel 'Der Aufstand der Niederlande: bürgerliche Revolution oder Elitenkonflikt?' (1976). Deze sociaal-historische beschouwing heeft grote verdiensten in vele opzichten, al wordt in het begin een driepartijenmodel gesuggereerd dat in de verdere uiteenzetting geen grote rol meer speelt. Niet als revolutie der burgerij alleen, maar als die van een coalitie van adel en (grote) burgerij, waarbij het calvinisme als geestelijk ferment diende, ziet Schilling de Opstand, waarbij hij in het voorbijgaan nog opmerkt dat het element van boerenverzet ten enenmale ontbreekt ${ }^{45}$.

In het afgelopen decennium hebben herdenkingen van belangrijke momenten uit de geschiedenis van de Opstand als de Pacificatie van Gent, de Unie van Utrecht, de Verlatinge, de dood van Oranje aanleiding gegeven tot velerlei publiciteit waarin Noord- en Zuidnederlandse historici de resultaten van hun voortgaande onderzoekingen hebben neergelegd. Ongetwijfeld hebben zij doorgaans de vereiste aandacht opgebracht voor het buitenlandse aandeel in de arbeid op een terrein dat zozeer tot de algemene geschiedenis van Europa behoort. Op één publikatie aan de vooravond van het Oranje-herdenkingsjaar 1984 verschenen moge hier ten slotte nog gewezen worden, het artikel van N.M. Sutherland ' William of Orange and the Revolt of the Netherlands, a Missing Dimension'. De onderzoekster van aspecten der Franse godsdienstoorlogen van dit tijdvak situeert Oranje hier als leidende figuur in de grote ideologische worsteling in Europa aan het hoofd van wie zich tegen de katholieke restauratiebeweging van het pausdom en Spanje kantten. Ook deze schrijfster noemt de Lage landen de 'political hub of western Europe ${ }^{146}$ en zij licht dat in het bijzonder toe aan de hand van de gebeurtenissen der jaren 1576-1578 onder de landvoogdij van Don Juan, die vanuit de Nederlanden in Engeland wilde interveniëren. Het is deze internationale dimensie van de Opstand en van de figuur van Oranje die de constante buitenlandse belangstelling ervoor verklaart als onmisbare bijdrage tot de studie van dit object.

44. H. Schilling, 'Calvinistische Presbyterien in Stadten der Frühneuzeit - eine kirchliche Alternativform zur bürgerlichen Reprasentation?', in: W. Ehbrecht, ed., Stadtische Führungsgruppen und Gemeinde in der werdenden Neuzeit (Keulen-Wenen, 1980) $385 \mathrm{vlg}$.

45. H. Schilling, 'Der Aufstand der Niederlande: bürgerliche Revolution oder Elitenkonflikt?', in: H.U. Wehler, ed., 200 Jahre amerikanische Revolution und moderne Revolutionsforschung (Göttingen, 1976) 202.

46. N.M. Sutherland, 'William of Orange and the Revolt of the Netherlands: a Missing Dimension', Archiv für Reformationsgeschichte, LXXIV (1983) 201. 


\section{De Republiek in buitenlandse handboeken}

\section{A.TH. VAN DEURSEN}

De mens hoort in voorspoed dankbaar, en in tegenspoed geduldig te zijn. Zo ook moeten wij dus omgaan met buitenlandse historici, die hebben geschreven over de geschiedenis van de Nederlandse Republiek. Voor dankbaarheid is reden genoeg. Van Laspeyres en Pringsheim tot Wilson en Jan de Vries hebben buitenlanders de economische en sociale geschiedenis van de zeventiende eeuw enorm verrijkt. Onder de politieke historici vond Johan de Witt in Lefêvre-Pontalis een Franse, in Geddes een Engelse, en in Herbert Rowen een Amerikaanse biograaf. De Tsjech Polisenky en de Engelsman Parker herplaatsten de oorlog tegen Spanje in zijn Europese kaders. De schilderkunst van de zeventiende eeuw heeft aandacht getrokken op alle niveau's van wetenschappelijkheid en popularisatie. Wie de beste werken van buitenlanders over de Nederlandse zeventiende eeuw in één artikel naar verdienste zou willen beschrijven, moet een grootmeester in de lofprijzing zijn.

Zoveel kwaliteit maakt nieuwsgierig. Als buitenlandse historici zo dikwijls met oordeel en begrip hebben geschreven over het Nederlandse verleden, zou het dan niet lonend zijn, kennis te nemen van hun algemene visies op de plaats en betekenis van de Republiek? En zouden we die wel ergens beter kunnen vinden dan in de grote handboeken, die over de Nederlanden zo kort moeten zijn dat onvermijdelijk de hoofdzaken naar voren komen, en die met grotere onbevangenheid het Nederlandse optreden kunnen plaatsen in zijn Europese omlijsting? Wij willen ons daarom nu als taak stellen, de plaats van de Republiek te onderzoeken in een aantal representatieve handboeken van gevarieerde herkomst en ouderdom. We zullen steeds vragen naar de algemene gezichtspunten, die eenheid geven aan de behandeling van de Nederlandse geschiedenis tussen 1588 en 1702, de bloeitijd van de Republiek. We gaan na hoe het Nederlandse verleden wordt ingepast in het Europese. En we toetsen de kwaliteit van de voorstelling aan de feitelijke kennis waarvan de auteurs blijk geven.

Het begin van de twintigste eeuw vormt dan een logisch startpunt. Omstreeks 1900 hebben Frankrijk, Duitsland en Engeland ieder een grote algemene geschiedenis zien uitkomen: Frankrijk de Histoire Générale van Ernest Lavisse en Al- 